\title{
LEAD POISONING IN THE INFANT AND YOUNG CHILD.
}

\author{
By LEONARD FINDLAY, M.D., D.Sc., \\ (Physician, Princess Elizabeth of York Hospital for Children.)
}

Lead poisoning in this country for the most part is a disease of industry and hence is usually met with in the adult. But the condition may be met with at any age and in some countries, e.g., Australia and Japan, it seems to be not uncommon in childhood. However, everywhere except perhaps in Japan it is rare during infancy, and, as the symptomatology during this period of life is often obscure and does not conform to the usually accepted classical description, the following case record as a reminder of the possibility of lead poisoning being the cause of the illness is not without interest.

\section{Case Record.}

The child, a female infant, came under observation at the age of $3 \frac{1}{2}$ months with the complaint that she was not thriving. The pregnancy had been full time, the labour normal and the child apparently healthy at birth weighing Io $\frac{1}{4}$ pounds. Breast-feeding had been practised for three months but, as the child was not doing well, this was stopped and bottle-feeding with cow's milk and water in equal quantities had been instituted.

On coming under observation the child was extremely pale and somewhat emaciated. A loud ventricular systolic murmur was heard all over the precordium with generalized wheezing throughout both lungs. The spleen was enlarged, being palpable $2 \frac{1}{2}$ fingerbreadths below the costal margin, and the liver's edge could be felt $3 \frac{1}{2}$ fingerbreadths below the costal margin.

Pirquet's tuberculin test and Wassermann's reaction were both negative.

Examination of the blood:

\begin{tabular}{|c|c|c|c|c|c|}
\hline Hæmoglobin & $\cdots$ & .. & $42 \%$ & & \\
\hline Red cells & $\ldots$ & $\ldots$ & $2,205,000$ & per & c.mm. \\
\hline Leucocytes ... & $\ldots$ & & I7,600 & " & " \\
\hline Colour index & $\ldots$ & $\ldots$ & I.O & & \\
\hline
\end{tabular}

Stained films showed 27 nucleated red cells while counting 320 leucocytes. A differential count of the leucocytes gave the following:

$\begin{array}{lllllll}\text { Lymphocytes } \ldots & \ldots & \ldots & \ldots & \ldots & 45.9 \% \\ \text { Neut. polymorphs } & \ldots & \ldots & \ldots & \ldots & 40.6,, \\ \text { E myelocytes } & \ldots & \ldots & \ldots & \ldots & 4.4, " \\ \text { Eosinophiles } & \ldots & \ldots & \ldots & \ldots & \ldots & 3.8, " \\ \text { Transitionals } \ldots & \ldots & \ldots & \ldots & \ldots & 4.7, \\ \text { Hyalines } & \ldots & \ldots & \ldots & \ldots & \ldots & 0.6, "\end{array}$

On account of the anæmia characterised by the presence of nucleated red cells and myelocytes, a moderate leucocytosis and the enlargement of the spleen in the absence of either a positive tuberculin or Wassermann test, even although the child was only $3 \frac{1}{2}$ months old, a provisional diagnosis of von Jaksch's anæmia was made and the citrate of iron and ammonium administered. 
One week after admission to hospital fever appeared with dulness to percussion and a harsh respiratory murmur over the right back. Next day (3rd May) definite pneumonic consolidation of the right upper lobe was apparent. On this day examination of blood films showed an occasional red cell with basophilic granulation but little emphasis was laid on the finding.

On 8th May a pemphigoid eruption appeared on the head and chest but culture of the contents of the bullæ was negative. On the Ioth May the blood was again examined with the following result:

$\begin{array}{llllll}\text { Hæmoglobin } & \ldots & \ldots & 50 \% \\ \text { Red cells } & \ldots & \ldots & \ldots & 3,480,000 & \text { per c.mm. } \\ \text { Leucocytes } \ldots & \ldots & \ldots & 22,800 \quad, & , \\ \text { Colour index } & \ldots & \ldots & 0.7 & \end{array}$

Differential count :

$\begin{array}{lcccccr}\text { Lymphocytes } & \ldots & \ldots & \ldots & \ldots & \ldots & 62.0 \% \\ \text { Neut. polymorphs } & \ldots & \ldots & \ldots & \ldots & 32.6,, \\ \text { Eosinophiles } & \ldots & \ldots & \ldots & \ldots & \ldots & \text {..6,", } \\ \text { Hyalines } & \ldots & \ldots & \ldots & \ldots & \ldots & \text { 1.3,", } \\ \text { Mast cells } & \ldots & \ldots & \ldots & \ldots & \ldots & \text {..3,", } \\ \text { Transitionals } & \ldots & \ldots & \ldots & \ldots & \ldots & 2.0,,\end{array}$

Stained films showed aninocytosis, some poikilocytosis and polychromasia with, in addition, an extreme degree of punctate basophilia.

The extreme degree of punctate basophilia present on this occasion at once suggested the diagnosis of lead poisoning and, on enquiring of the mother of any possible source of lead, it was learned that owing to sore nipples she had, all the time the child was at the breast, protected them by the use of leaden shields (Dr. Wansborough's metallic shields). These were applied between the feedings and neither the nipples nor the shields (which on inspection were found to be much corroded) were ever washed.

It was now apparent that we had ample justification for the suspicion of lead poisoning raised by the blood finding but, although the anæmia had definitely improved, the fever continued, the pneumonic consolidation presented no signs of resolving, the pemphigoid eruption became more extensive, a B.coli infection of the urinary tract developed and the child died on I6th May, three weeks after admission to hospital and two weeks after the onset of pneumonia. As the nature of the case necessitated that the death be reported to the Procurator Fiscal no opportunity for a post-mortem examination was given.

\section{Symptoms of Lead Poisoning in Infancy.}

Although ancemia is one of the most characteristic manifestations of both acute and chronic plumbism it usually results only after prolonged absorption of the metal and thus is seldom met with in infancy. Moreover, it is also worth bearing in mind that punctate basophilia, which is the particular feature of the blood picture which gives the clue to the diagnosis, is usually absent in the early stages. It was because of this fact that a correct diagnosis was not made when the child first came under observation.

A similar instance in which the clue to the diagnosis was given by the blood finding is recorded by Holt. ${ }^{(1)}$ This affected a child of eight months who had been becoming increasingly pale and for which she had been receiving iron when 
suddenly convulsions developed. At this period of the illness the child had only a slight degree of anæmia (hæmoglobin 67\%, red cells 3,800,000 per c.mm.) and because there was a questionable positive Trousseau, a slight degree of increased electrical excitability (Erb's phenomenon) and definite cranio-tabes, tetany was diagnosed. Some few days later a routine examination of the blood revealed that there had developed a high degree of basophilia which, as in our case, immediately raised the question of lead poisoning. Renewed enquiry of the mother then elicited the fact that she had had sore nipples and had been applying a diachylon plaster which contains acetate of lead.

Convulsions, as were present in Holt's case, would seem to be the commonest manifestation of lead poisoning in infancy. The infant cerebrum would appear to be specially susceptible to the poison as does that of the younger female worker, in whom lead encephalopathy has always been known to be particularly frequent and dangerous. In lead encephalopathy the cerebro-spinal fluid usually. presents changes which must be appreciated or an error in diagnosis might arise. The cerebro-spinal fluid contains an excessive amount of globulin and at the same time the cells, chiefly of the lymphocytic type, show a slight increase varying between 30 and Ioo per c.mm. so that poliomyelitis, tubercular or syphilitic meningitis, and abscess or tumour of the brain might be suspected. However, lead encephalopathy as a rule is also accompanied by a neuro-retinitis with swelling of the disc and hæmorrhages in the retina, an unusual finding in any of the above conditions except tumour. But that a diagnosis of cerebral tumour might easily be made, if the possibility of lead poisoning were not considered, is evident from the writings of J. Lockhart Gibson ${ }^{(2)}$ of Queensland. This author states that in Queensland vomiting without any relation to the taking of food, headache, ocular paralysis and optic neuritis may be the sole clinical manifestations of lead poisoning in the child. For the syndrome Gibson gives the name "ocular plumbism." The true nature of the malady is demonstrated by the presence of lead in the urine, and the cause of the symptoms Gibson ascribes to a mild degree of hydrocephalus raising the intra-cranial pressure.

The two classical manifestations-the blue line on the gums and drop wristare rare in infancy, and indeed throughout childhood. The extreme rarity of the blue line on the gums is understandable because this sign is dependent on the formation of lead sulphide through the action of sulphuretted hydrogen produced from the putrefaction of food and organic matter in carious teeth. Thus from the absence of teeth during infancy and the absence of caries during the early years of life the conditions essential for its production do not arise.

While wrist-drop is rare in infancy and childhood, lead palsy is not, but unlike what occurs in the adult, it most frequently affects the lower limbs. In the adult the proportion of upper to lower limb palsies is Ioo to I3, whereas in the child this ratio is practically reversed.

Colic, the other symptomatic partner of the classical triad, may occur in the child but it is undoubtedly less frequent and less severe than in the adult, and in any case its appraisement is always a matter of the most extreme difficulty in the early years of life.

\section{Source of the Lead.}

The source of the lead is variable. In the infant, as in our own case and that of Holt, it most frequently arises from the application of some preparation of lead to the mother's nipples. In Japan, Hirai ${ }^{(3)}$ states that the source is a 
white face powder containing lead used by the mother which the child not only ingests but also inhales. One would have expected that for this reason the condition would have been equally frequent in the breast-fed and the bottle-fed child, but according to Hirai it is more commonly met with in the breast-fed child which fact he explains by stating that the lead is excreted in the milk.

In the older child the source is usually the paint work of toys and bed or cot rails, and in Queensland Gibson traced the cause to the paint work of the railings of the verandahs which, with the heat of the summer, was converted into a fine powder and became easily attached to the hands of the child which are unduly moist at this season of the year. That the lead enters the child's system by ingestion, and not by inhalation, is suggested by the fact that keeping the nails short and washing of the hands renders the development of the malady less likely.

\section{Congenital Plumbism.}

In any discussion of plumbism in the child and its cause mention must be made of the possibility of the child being affected in utero-the so-called congenital plumbism. Abortion and still birth are well recognised results of lead-poisoning in the pregnant woman and it has always been known that the children of women affected are liable to be puny, to suffer from convulsions and to be mentally deficient. One can easily understand the child suffering if the mother herself is the subject of lead poisoning because the poison may reach the foetus viâ the placental circulation. In the case of the affected father conditions are otherwise, yet Dr. John Thomson (4) records the interesting history of a consecutive series of four children of a healthy mother but of a father the subject of a long unrecognised lead poisoning. All four children developed within the third and sixth months convulsions of precisely the same nature and from which they all succumbed between the ages of eight and eighteen months. The two first children of the union, conceived before the father had come in contact with lead, were quite healthy and hence there is little probability of the lead per se being the cause of the children's illness but rather some peculiarity of the germ cell induced by the lead. A quite parallel state of matters has been induced experimentally in guinea-pigs by the administration of alcohol. Stockhard ${ }^{(5)}$ showed that when alcoholized male guinea-pigs were mated with normal females conception often did not result but, when it did, abortion, still-birth or malformation of the fotus frequently occurred, and any progeny born alive presented nervous symptoms. These bad effects were found not only in the first litter, but were present to a certain extent in the second and third generations, results which could only be attributed to the spermatozoa being seriously damaged by the alcohol.

\section{Diagnosis.}

The diagnosis of lead poisoning rests in the first place on having in mind its possibility, more especially in any anomalous blood or cerebral condition. Examination of the blood might reveal the characteristic basophilia and examination of the urine and fæces might disclose the presence of lead, though it is only when this is present in the urine that we can guarantee that it has been absorbed and thus has been able to exert its toxic effect. The blue line-Burton's lineon the gums, as already remarked, is seldom if ever met with in childhood, so that one of the most important diagnostic features cannot be depended upon. 
However, this serious loss has in some part been compensated for by a recently described sign and one which is only available in infancy and early childhood, viz., the so-called lead line in the radiogram. ${ }^{(6)}$ It seems that during the period of most rapid osseous growth the ingested lead combines with phosphorus forming an insoluble phosphate of lead which obscures the X-rays and casts a dense, sharplydefined shadow at the diaphyseal ends of the bones. This sign, which recalls the picture induced by the prolonged ingestion of phosphorus, is not only of value in demonstrating the existence of lead poisoning but also by its extent, i.e., the width of the area of condensation, gives some idea of the length of time during which lead has been ingested. Unfortunately, however, this sign is not available during the whole of childhood, since it is only present during the period of most active growth and so far has never been observed in any child over two and a half years old. ${ }^{(7)}$

\section{Treatment.}

The first thing to do in the way of treatment is of course to stop any possibility of further absorption. This is easily accomplished when the source of the lead has been discovered. The excretion of the metal by the urine, which has been going on all the time, will gradually bring about its complete elimination. It is now no longer considered advisable or advantageous in any way to administer the iodide of potassium with the hope of hastening this excretion.

Anæmia when present is treated by the administration of some ferruginous preparation and none seems more efficacious than the citrate of iron and ammonium in doses of 15 to 30 grains or more per day.

In lead palsy the weakened muscles should be supported by splints as is done in the case of poliomyelitis and, as recovery takes place, the use of massage and graduated exercises will be found of value.

It is in the case of lead encephalopathy that most urgent measures are required. Convulsions may necessitate the administration of sedatives but Gibson recommends repeated lumbar puncture as the most efficacious measure. According to this author, even in the presence of optic neuritis, repeated lumbar puncture, by diminishing the intracranial pressure, may bring about a complete restoration to health and hinder the development of optic atrophy with impairment of vision, perhaps the most disastrous sequela of lead encephalopathy.

(1) Holt, Junr., L. E., Amer. Jour. Dis. Child., 1923, xxv, 229

(2) Gibson, J. Lockhart, Brit. Jour. Ophthalmology, 1931, xv, 637.

(3) Hirai, I., Bull. Orient. Ohild Health, A., Infant Series, 1927, 1, 1.

(4) Thomson, John, Brit. Jour. Child. Dis., 1923, Xx, 193.

(5) Stockhard, C. R., Brit. Med. Jour., 1922, 11, 255.

(6) Vogt, E. C., Amer. Jour. Rœngtol., 1930, xxiv, 550.

(7) Kasahara, M., Jour. Expt. Med., 1931, xvili, 146. 